\title{
Obesity and Metabolic Syndrome in a Burkina Faso Urban Area: Prevalence, Associated Factors and Comorbidities
}

Yempabou Sagna $^{1 *}$, Donald AugusteRayagnéwendé Yanogo ${ }^{1}$, Hervé Tiéno ${ }^{1,2}$, Oumar Guira ${ }^{1,2}$, Abraham $\mathbf{P}$ Bagbila1, Réné Bognounou ${ }^{1}$, Lassane Zoungrana1, Dieu-Donné. Ouédraogo ${ }^{1,2}$ and Youssouf Joseph Drabo ${ }^{1,2}$

${ }^{1}$ Internal Medicine Department, YalgadoOuédraogo Teaching Hospital, BP 7022, Ouagadougou 03, Burkina Faso

${ }^{2}$ UFR/SDS, University of Ouagadougou 03 BP 7021, Burkina Faso, France

*Corresponding author: Yempabou Sagna, 09 BP 628 Ouagadougou 09. Burkina Faso, France, Tel: +226 71221937; E-mail: my_sagna@yahoo.fr

Rec Date: 11 Apr 2014, Acc Date: 16 Jun 2014, Pub Date: 18 Jun 2014

Copyright: @2014 Sagna Y, et al. This is an open-access article distributed under the terms of the Creative Commons Attribution License, which permits unrestricted use, distribution, and reproduction in any medium, provided the original author and source are credited.

\section{Abstract}

Background: The prevalence of obesity and metabolic syndrome is not just a problem of the developed countries but is also with a growing trend in developing countries, especially in urban areas. We aimed to estimate the prevalence of obesity and metabolic syndrome in the urban population living in Ouagadougou, Burkina Faso, and to investigate the factors and comorbidities associated with them.

Methods: Data were collected in two rounds (in March and December 2011) from two different neighbourhoods (peripheral and central) of Ouagadougou. We included all over 20 year old volunteers' subjects (excluding pregnant women). All characteristics were collected during face-to-face interviews. We used international standards to define obesity, hypertension and metabolic syndrome. The statistical analysis used chi-square (chi 2 ) tests and odds ratio with $95 \%$ confidence interval.

Results: 632 subjects with a mean age of $41.3 \pm 6.8$ years [20-75 years] and sex ratio (men/women) of 0.9 were included in this survey. Overall crude prevalence of overweight, obesity and metabolic syndrome were respectively $30.5 \%, 22 \%$ and $7 \%$. Compared with normal weight participants, obese individuals had more hypertension, diabetes or impaired fasting glucose $(p=0.000)$, and they were more likely to be older, women, employed and living in the central neighbourhood. Obesity was found in $81.8 \%$ of subjects with metabolic syndrome. On bivariate analysis, those with the metabolic syndrome were female, older, and obese

Conclusion: The prevalence of obesity and metabolic syndrome in urban Burkina Faso is high. There is a need to pay closer attention to combating these health disorders. An important place must be reserved for the prevention and the fight against obesity by appropriate lifestyle.

Keywords: Obesity; Metabolic syndrome; Urban areas; Burkina faso; Sub-saharan africa

\section{Introduction}

The global epidemic of overweight and obesity is rapidly becoming a major public health problem in many parts of the world. Overweight and obesity lead to adverse metabolic effects on blood pressure, cholesterol, triglycerides and insulin resistance [1]. They are associated with many diet-related chronic diseases including diabetes mellitus, cardiovascular disease, stroke, hypertension and certain cancers [2].

In 2008, 35\% (over 1 billion) of adults aged 20 and over were overweight worldwide, and $11 \%$ were obese [3]. The World Health Organization (WHO) indicate that the prevalence of obesity is not just a problem of the developed countries but is also with a growing trend in developing countries, with over 115 million people suffering from obesity-related problems [1]. This significant acceleration in the incidence of obesity also indicates that low-income countries are now confronted with a double burden where both communicable and chronic non-communicable diseases co-exist.

Almost half the disease burden in low-and-middle-income countries is now from non-communicable diseases [4,5]. Previous studies shown that the prevalence of obesity in West Africa was estimated at $10.0 \%$ [5], Obesity is thus becoming a pressing publichealth problem for sub-Saharan Africa (SSA).

Burkina Faso is a West Africa tropical country. According to the last census of the National Institute of Statistics and Demographics of Burkina Faso (Institut National de la Statistique et de la Démographie du Burkina Faso) in 2009, a total of 1029584 individuals with at least 20 years old were living in the urban municipality of Ouagadougou [6]. One previous study performed in Ouagadougou in 2004, focused only on obesity, shown that this prevalence was about 14\% [7]. According to forecasts, the urban municipality of Ouagadougou has an annual growth rate of $7.6 \%$, and the population doubled at each decade [6]. As others low-and-middle-income countries, undernutrition and communicable infectious diseases remain a core focus of researchers and policy makers. Quantifying the prevalence obesity and metabolic syndrome to highlight trends and evaluating theirs associated factors is important to draw health policy makers attention to address this problem. The aim of this study was to describe the prevalence of overweight, obesity and metabolic syndrome (MetS) in Ouagadougou and to investigate the associated factors or comorbidities. 
Citation: Sagna Y, Yanogo DA, Tieno H, Guira O, Bagbila A et al. (2014) Obesity and Metabolic Syndrome in a Burkina Faso Urban Area:

\section{Methods}

\section{Population sample}

A cross-sectional survey was implemented in two rounds (in March and December 2011) in two different neighbourhoods of Ouagadougou: one central with high building density and one peripheral with middle and low building density.

A sample size of 340 individuals for each neighbourhood was adequate on the basis of an estimated prevalence of $33 \%$ of overweight/obesity [8]. The precision was $5 \%$, with $95 \%$ confidence interval (CI) and 5\% marginal of error. The size of each sample was increased by $5 \%$ up to 357 , to provide for incomplete data sets. A Zvalue of 1.96 used at $95 \% \mathrm{CI}$.

$\mathrm{n}=[\mathrm{Z} 2 \times \mathrm{p} \times \mathrm{q}] / \mathrm{i} 2(\mathrm{n}=$ sample size, $\mathrm{p}=$ prevalence, $\mathrm{q}=1-\mathrm{p}, \mathrm{i}=$ margin of error).

Each round was preceded by 02 days of information campaigns using advertisements by the national television channel, the national broadcasting, and 03 private broadcasting of Ouagadougou. Information was given in French language and then translated into the 02 most spoken national languages (Moré and Dioula). He was asked volunteers to come fasting (at least 8 hours, excluding water) in the screening center at morning between 7AM and $12 \mathrm{AM}$.

Pregnant women and people younger than 20 years were excluded from the study.

Each survey team was composed by nurses and physicians. Data were collected using an oral applied questionnaire form, containing age, gender (male/female), employment status, medical history status (diabetes, hypertension), clinical, and glucose data sections was used for data collection for each patient. To standardize survey measurements and procedures, each survey team was trained. All field workers were trained and certified to administer the questionnaire, measure waist circumference, take blood pressure measurements and draw blood.

\section{Variables studied}

\section{Socioeconomic variables:}

The questionnaire was orally translated into Mooré (mossi ethnic group language) or Dioula for persons who did not understand French. Then we made some categories for age (20-29/30-39/40$49 / 50-59 / \geq 60$ years) and profession (employed/unemployed).

\section{Body Mass Index:}

\section{Waist circumference:}

\section{Blood pressure:}

\section{Glycemic control:}

\section{Operational definitions:}

The BMI values were classified into 4 groups according to the WHO criteria (BMI $<18,5$ : underweight $; 18,5 \leq \mathrm{BMI} \leq 24,9$ : normal weight; $25 \leq \mathrm{BMI} \leq 29,9$ : overweight; $\mathrm{BMI} \geq 30$ : obesity. For purposes of analysis we classified all subjects with a BMI $\geq 25 \mathrm{~kg} / \mathrm{m}^{2}$ as overweight or obese.

Hypertension was defined as a systolic BP greater than or equal to $140 \mathrm{mmHg}$ and/or a diastolic BP greater than or equal to $90 \mathrm{mmHg}$ or reported treatment for hypertension.

The metabolic syndrome was defined using the International Diabetes Federation criteria for the waist circumference, the blood pressure and the raised blood [10,11]. Given the limited resources and poor infrastructure during the screenings, it was not possible to make the blood lipid assays.

\section{Statistical analysis}

Data were recorded and analyzed using Predictive Analytics Software (PASW Statistics) version 18. Data are expressed as mean \pm standard deviation (SD). The Student's unpaired, two-sided t-test was used to compare means between two groups. The Chi-square $\left(\chi^{2}\right)$ test was used in the comparison of proportions. The strength of association between the dependent variables was assessed using odds ratio (OR). To identify factors associated with the MetS among various groups, we first performed a bivariate comparison of the prevalence of MetS using the $\chi^{2}$ test. Variables associated with the MetS with a $\mathrm{P}<0.10$ on bivariate analysis were then considered for multivariate regression.

\section{Ethical considerations}

The study was approved by the Ethics Committee for Health Research of Burkina Faso. The study objectives were clearly explained to participants, selected household heads and local authorities. All subjects were voluntarily disclosed. We have obtained from each subject oral informed consent prior to enrolment. They were given back their results on blood pressure and glycaemia, and those with abnormal values were referred for diagnosis and treatment.

\section{Results}

\section{Characteristics of all subjects}

A total of 632 subjects (central area: 321, peripheral area: 311, response rate: $88.5 \%$ ) with the mean age of $41.3 \pm 6.8$ years [20-75 years] completed the study. The main characteristics are described in Table 1. 
Citation: Sagna Y, Yanogo DA, Tieno H, Guira O, Bagbila A et al. (2014) Obesity and Metabolic Syndrome in a Burkina Faso Urban Area:

Page 3 of 6

\begin{tabular}{|c|c|c|c|c|c|}
\hline & & Gender & & & \\
\hline Variables & $\begin{array}{l}\text { Number of subjects } \\
(\%)\end{array}$ & Women (\%) & Men $(\%)$ & $\begin{array}{l}\text { Odds Ratio } \\
{[95 \% \mathrm{Cla}]}\end{array}$ & $P$ value \\
\hline $\begin{array}{l}\text { Medical history } \\
\text { Diabetes } \\
\text { Hypertension }\end{array}$ & \begin{tabular}{|l}
$47(7.4)$ \\
$104(16.5)$
\end{tabular} & $\begin{array}{l}33(10.1) \\
62(18.9)\end{array}$ & $\begin{array}{l}14(4.6) \\
42(13.8)\end{array}$ & $\begin{array}{l}2.32[1.23-4.54] \\
1.45[0.95-2.24]\end{array}$ & $\begin{array}{l}0.009 \\
0.084\end{array}$ \\
\hline $\begin{array}{l}\text { Employment statusb } \\
\text { Unemployed } \\
\text { Employed }\end{array}$ & $\begin{array}{l}227(36) \\
404(64)\end{array}$ & $\begin{array}{l}158(48.3) \\
169(51.8)\end{array}$ & $\begin{array}{l}61(20.1) \\
243(79.9)\end{array}$ & $\begin{array}{l}3.70[2.60-5.29] \\
0.27[0.19-0.38]\end{array}$ & $\begin{array}{l}0.000 \\
0.000\end{array}$ \\
\hline $\begin{array}{l}\text { Age range (years) } \\
20-29 \\
30-39 \\
40-49 \\
50-59 \\
\geq 60\end{array}$ & $\begin{array}{l}164(25.9) \\
154(24.4) \\
172(27.2) \\
104(16.5) \\
38(6)\end{array}$ & $\begin{array}{l}90(27.4) \\
75(22.6) \\
94(28.7) \\
53(16.2) \\
16(4.9)\end{array}$ & $\begin{array}{l}74(24.3) \\
79(26) \\
78(25.7) \\
51(16.8) \\
32(10.2)\end{array}$ & $\begin{array}{l}1.18[0.82-1.68] \\
0.84[0.59-1.22] \\
1.16[0.81-1.66] \\
0.96[0.63-1.46] \\
0.44[0.23-0.81]\end{array}$ & $\begin{array}{l}0.374 \\
0.319 \\
0.397 \\
0.839 \\
0.011\end{array}$ \\
\hline Mean age (years) & 41.3 & 40.2 & 42.4 & - & 0.048 \\
\hline $\begin{array}{l}\text { BMIc(Kg/m2) } \\
<18,5 \\
18,5-24,9 \\
25-29,9 \\
\geq 30\end{array}$ & $\begin{array}{l}32(5.1) \\
268(42.4) \\
193(30.5) \\
139(22)\end{array}$ & $\begin{array}{l}11(3.4) \\
111(33.8) \\
96(29.3) \\
110(33.5)\end{array}$ & $\begin{array}{l}21(6.9) \\
157(51.6) \\
97(31.9) \\
29(9.5)\end{array}$ & $\begin{array}{l}0.47[0.21-0.98] \\
0.48[0.35-0.66] \\
0.88[0.63-1.24] \\
4.78[3.08-7.55]\end{array}$ & $\begin{array}{l}0.045 \\
0.000 \\
0.478 \\
0.000\end{array}$ \\
\hline Mean BMI (Kg/m2) & 26.2 & 28.1 & 24.3 & - & 0.000 \\
\hline Metabolic syndrome & $44(7)$ & $31(9.5)$ & $13(4.3)$ & $2.34[1.21-4.69]$ & 0.010 \\
\hline Hypertension & $178(28.2)$ & $97(29.6)$ & $81(26.7)$ & $1.16[0.82-1.64]$ & 0.418 \\
\hline
\end{tabular}

Table 1: Characteristics of all subjects

\begin{tabular}{|l|l|l|l|l|l|}
\hline & Overall (\%) & Central neighbourhood (\%) & $\begin{array}{l}\text { Peripheral } \\
\text { neighbourhood (\%) }\end{array}$ & Odds Ratio [95\% Cla] & P value \\
\hline Overweight & $193(30.5)$ & $106(33)$ & $87(28)$ & $1.27[0.90-1.79]$ & 0.17 \\
\hline Obesity & $139(22)$ & $92(28.7)$ & $47(15.1)$ & $2.26[1.52-3.36]$ & $1.76[0.94-3.39]$ \\
\hline MetSb & $44(7)$ & $28(8.7)$ & $16(5.2)$ & 0.001 & 0.08 \\
\hline aCl: Confidence interval; bMetS: metabolic syndrome
\end{tabular}

Table 2: Comparison of overweight, obesity and metabolic syndrome between the peripheral and the central neighbourhood

\begin{tabular}{|c|c|c|c|c|c|c|}
\hline Factors & Categories & $\begin{array}{l}\text { Number } \quad \text { of } \\
\text { subjects }\end{array}$ & $\begin{array}{l}\text { MSa cases } \\
(\%)\end{array}$ & $\begin{array}{l}\text { Odds Ratio } \\
{[95 \% \text { Clb] }}\end{array}$ & $\begin{array}{l}P \quad \text { value }(\mathrm{bi}- \\
\text { variate analysis) }\end{array}$ & $\begin{array}{l}P \quad \text { value (multi- } \\
\text { variateanalysis) }\end{array}$ \\
\hline Gender & $\begin{array}{l}\text { Women } \\
\text { Men }\end{array}$ & $\begin{array}{l}328 \\
304\end{array}$ & $\begin{array}{l}31(9.5) \\
13(4.3)\end{array}$ & $2.34[1.21-4.69]$ & 0.010 & 0.048 \\
\hline Age range (years) & $\begin{array}{l}20-39 \\
40-59 \\
\geq 60\end{array}$ & $\begin{array}{l}318 \\
276 \\
38\end{array}$ & $\begin{array}{l}05(1.6) \\
37(13.4) \\
2(5.3)\end{array}$ & $\begin{array}{l}1 \text { (reference) } \\
9.69[3.97-28.11] \\
3.48[0.45-18.22]\end{array}$ & 0.000 & 0.000 \\
\hline
\end{tabular}


Citation: Sagna Y, Yanogo DA, Tieno H, Guira O, Bagbila A et al. (2014) Obesity and Metabolic Syndrome in a Burkina Faso Urban Area:

Page 4 of 6

\begin{tabular}{|l|l|l|l|l|l|l|}
\hline Employment statusc & Unemployed & 227 & $15(6.6)$ & $1.091[0.57-2.13]$ & 0.77 & - \\
& Employed & 404 & $29(7.2)$ & & & \\
\hline Neighborhood & Central & 321 & $28(8.7)$ & $1.76[0.94-3.39]$ & 0.08 & 0.685 \\
& Peripheral & 311 & $16(5.2)$ & & & \\
\hline BMId (Kg/m2) & $<30$ & 493 & $8(1.6)$ & $15.98[7.26-37.95]$ & 0.000 & 0.000 \\
& $\geq 30$ & 139 & $36(25.9)$ & & & 0.001 \\
\hline BMI(continuous) & - & - & & & 0.05 \\
\hline aMetS: metabolic syndrome; bCl: Confidence interval; cwe exclude one retired; dBMI: Body Mass Index & \\
\hline
\end{tabular}

Table 3: Comparison of selected factors according to the presence or absence of the metabolic syndrome

The subjects consisted of 328 women and 304 men with a sex ratio (M / W) of 0.9. Three hundred and seventeen subjects (50.2\%) were under 40 years and $315(47.8 \%)$ had at least 40 years. Four hundred and four subjects (64\%) led gainful employment.

The mean BMI was $26.1 \pm 5.2 \mathrm{~kg} / \mathrm{m} 2$ (95\% CI, 23.40-37.93). The mean waist circumference was $93.93 \mathrm{~cm}(95 \% \mathrm{CI}, 73-131)$ for women and $92.03 \mathrm{~cm}(95 \% \mathrm{CI}, 73-125)$ for men.

In terms of medical history, 47 subjects $(7.4 \%)$ were previously diagnosed diabetic patients and $104(16.5 \%)$ previously diagnosed hypertension.

The prevalence of overweight, obesity and MetS were respectively $30.5 \%(n=193), 22 \%(n=139)$ and $7 \%(n=44)$ (Table 2$)$.

\section{Associated factors}

Among overweight subjects, $15.5 \%$ had hypertension, and $6.7 \%$ had diabetes mellitus (newly and previously diagnosed).

The mean age was $47.5 \pm 9.7$ years for obese subjects and $37.5 \pm$ 11.2 years for non-obese subjects $(\mathrm{p}=0.000)$. Fifty-four percent of obese subjects had hypertension (vs $9.1 \%$ in non-obese subjects, OR: 11.67 [95\% CI, 7.40-18.36], $\mathrm{p}=0.000$ ). The prevalence of impaired fasting glucose and diabetes was respectively $22.3 \%$ among obese subjects vs $4.5 \%$ for non-obese subjects (OR: $6.15[95 \% \mathrm{CI}$, $3.41-11.12$ ], $\mathrm{p}<0.001)$ and $16.5 \%$ among obese subjects vs $3 \%$ for nonobese subjects (OR: 6.32 [95\% CI, 3.19-12.70], p<0.001).

Compared with normal weight participants, obese individuals were more likely to be older, women, and employed.

Obesity was found in $81.8 \%$ of subjects with MetS. On bivariate analysis, those with the MetS were female, older, and were obese (Table 3).

\section{Discussion}

The main limitation of the present study is its realization in urban areas that is not representative of the population of Burkina Faso. Further studies in other urban and rural areas and among other socioethnic groups are required to obtain an overall picture of the prevalence of obesity and MetS in Burkina Faso. In addition the crosssectional design of this study does not allow longitudinal evaluation to examine how obesity and MetS have evolved over time.

Nevertheless, this study provides an estimate of the prevalence of the MetS and some associated comorbidities in urban Burkina Faso.
These data could provide baseline figures for the guide planning of health care policy and establishment of medical priorities in Ouagadougou, the most urbanized region of Burkina Faso [6].

The higher mean BMI of our population reported tendency to overweight and obesity. Indeed, over half of the subjects were at least overweight and 22\% were obese in Ouagadougou. Women were more often overweight or obese $(\mathrm{p}=0.000)$. This prevalence is higher than the previous 2004 rate $(14.7 \%$ for obesity and $33 \%$ for both overweight and obesity), using a population-based cross-sectional survey reported in Ouagadougou $[7,8]$ with also female predominance. Age, gender, household equipment index (residents from structured and high building-density areas are more likely to be obese than those from unstructured and low building-density areas), usual transport with motor vehicles and micronutrient-rich food consumption are the factors associated with obesity in Ouagadougou [7].

Our results were close to those of N'Djamena and Libreville where half of the population are overweight [12]. However, according to studies in other urban areas of SSA, the prevalence of obesity varies from $8.3 \%$ in Senegal to $37 \%$ in Cameroon, through $8.9 \%$ in Gabon, $11.5 \%$ in Mali, $13.8 \%$ in Ivory Coast, $16.1 \%$ in Ghana, $19.5 \%$ in Guinea, $21.5 \%$ in Benin and $22.5 \%$ in Nigeria [12-20]. The high rates noted in our study and in these studies could be an indication of a raising of obesity in sub-Saharan Africa, although sampling strategy varied from one study to another.

Being women were strongly associated with obesity. Overall in SSA the prevalence of overweight and obesity is higher among women $[5,12,17-20]$. This female predominance could be explained by pregnancies [21] and socio-cultural motivations. In many sub-Saharan countries being overweight is indeed considered as a criterion of beauty and well-being in women.

Obese subjects had significantly more hypertension, impaired fasting glucose or diabetes than non-obese subjects. These findings support the fact that overweight and obesity lead to adverse metabolic changes such as insulin resistance and increasing blood pressure [1]. Consequently, they could promote the burden of cardiovascular diseases, diabetes and many types of cancer in Ouagadougou and Burkina Faso or others SSA countries urban areas [4,5,22,23].

The association between obesity and age, found also in others SSA countries $[5,20]$, supports the conclusion that the prevalence of obesity is expected to increase with the aging of the population. This high frequency can be explained in part by the increase in life expectancy and sedentary lifestyles in developing countries. 
The MetS is not uncommon in Ouagadougou. Indeed, using 03 of the IDF criteria, we found it in $7 \%$ of our subjects with no significant difference between the peripheral and the central neighbourhood. One previously study in 2010 [24], using the National Cholesterol Program Education-Adult Treatment Panel III criteria [25], found a prevalence of $10.3 \%$ of MetS in Ouagadougou. This MetS was associated with age, being female and general obesity. The influence of the number of pregnancies on the waist circumference could explain in part the predominance of women with MetS [21]. One other study in Ivory Coast, using also the National Cholesterol Program Education-Adult Treatment Panel III criteria, shown a $4.94 \%$ of MetS prevalence [16], but with no association with age and sex. In Africa, the definition criteria for MetS varies from one study to another. Then, assuming the fact that there is an ethnic difference in the relationship between abdominal adiposity and metabolic disease risk, some authors say that waist circumference cut point used for the diagnosis of MetS in SSA Women is not appropriate [26].

Nevertheless, the hypothesis that demographic transition (the increase in life expectancy leading to an increasingly elderly population) is at the root of the increase of the prevalence obesity and especially central obesity with MetS, has been confirmed by our findings.

The acceleration of urbanization in Africa, sedentary lifestyle and the present epidemiological transition in SSA so-called westernization of lifestyle - characterized by decreased amounts of physical activity and increased consumption of energy-dense or high-fat diets as a result of rapid urbanization are factors that increase the prevalence of obesity and therefore, metabolic syndrome and cardiovascular risk $[5,20,23]$. For these reasons, preventing obesity intervention programs designed to reduce waist circumference through lifestyle modification, including exercise and diet, may have important public health significance in reducing the incidence obese related diseases.

\section{Conclusion}

Obesity is fast becoming a public health problem in sub-Saharan Africa. This study shown that the prevalence of obesity in urban Burkina is high, which lead to a rising of hypertension and glucose disorders. It is necessary to develop effective health policies to address this problem. There is a need to pay closer attention to combating these health disorders. An important place must be reserved for the prevention and the fight against obesity by appropriate lifestyle.

\section{Acknowledgement}

No funding received. The authors have received no involvement, financial or otherwise, to perform this study.

\section{References}

1. [No authors listed] (2000) Obesity: preventing and managing the global epidemic. Report of a WHO consultation. World Health Organ Tech Rep Ser 894: i-xii, 1-253.

2. Caballero B (2007) The global epidemic of obesity: an overview. Epidemiol Rev 29: 1-5.

3. World Health Organization (2013) Obesity and overweight. Fact sheet N ${ }^{\circ} 311$.

4. Lopez AD1, Mathers CD, Ezzati M, Jamison DT, Murray CJ (2006) Global and regional burden of disease and risk factors, 2001: systematic analysis of population health data. Lancet 367: 1747-1757.
5. Abubakari AR, Lauder W, Agyemang C, Jones M, Kirk A, et al. (2008) Prevalence and time trends in obesity among adult West African populations: a meta-analysis. Obes Rev 9: 297-311.

6. Institut National de la Statistique et de la Démographie La région du Centre en chiffres (Projections de la population de 2007 à 2020).

7. Ouédraogo HZ, Fournet F, Martin-Prével Y, Gary J, Henry MC, et al. (2008) Socio-spatial disparities of obesity among adults in the urban setting of Ouagadougou, Burkina Faso. Public Health Nutr 11: 1280-1287.

8. Niakara A, Fournet F, Gary J (2007) Hypertension, urbanization, social and spatial disparities: a cross-sectional population-based survey in a West African urban environment (Ouagadougou, Burkina Faso). Trans $\mathrm{R}$ Soc Trop Med Hyg.

9. World Health Organization (2011) Waist circumference and waist-hip ratio: report of a WHO expert consultation, Geneva, 8-11 December 2008. World Health Organization, Geneva

10. Alberti KG, Zimmet P, Shaw J; IDF Epidemiology Task Force Consensus Group (2005) The metabolic syndrome--a new worldwide definition. Lancet 366: 1059-1062.

11. Alberti KGMM, Eckel RH, Grundy SM (2009) Harmonizing the Metabolic Syndrome: A Joint Interim Statement of the International Diabetes Federation Task Force on Epidemiology and Prevention; National Heart, Lung, and Blood Institute; American Heart Association; World Heart Federation; International Atherosclerosis Society; and International Association for the Study of Obesity. Circulation 120: 1640-1645.

12. WHO STEP wise approach to chronic disease risk factor surveillance.

13. Duboz P, Chapuis-Lucciani N, Boëtsch G, Gueye L (2012) Prevalence of diabetes and associated risk factors in a Senegalese urban (Dakar) population. Diabetes Metab 38: 332-336.

14. Epacka Ewane M, Mandengue SH, Ahmadou G (2011) Dépistage des maladies cardiovasculaires et des facteurs de risque dans une cohorte de 270 Camerounais?: effets des activités physiques et sportives. Médecine Mal Métaboliques 5: 655-658.

15. Sidibé A, Traore A, Traore D (2014) P185 Profil lipidique chez les obèses diabétiques et les obèses non diabétiques. Diabetes Metab 40: A72.

16. Hauhouot-Attoungbre ML, Yayo SE, Ake-Edjeme A (2008) Le syndrome métabolique existe-t-il en Côte d'Ivoire?? Immuno-Anal Biol Spéc 23: 375-378.

17. Biritwum R, Gyapong J, Mensah G (2005) The epidemiology of obesity in ghana. Ghana Med J 39: 82-85.

18. Baldé NM, Diallo I, Baldé MD, Barry IS, Kaba L, et al. (2007) Diabetes and impaired fasting glucose in rural and urban populations in Futa Jallon (Guinea): prevalence and associated risk factors. Diabetes Metab 33: 114-120.

19. Djrolo F, Gbary A, Akoha SER (2012) Prévalence de l'obésité et de la surcharge pondérale dans population adulte à Cotonou, Bénin. Ann Endocrinol 73: 424.

20. Chukwuonye II, Chuku A, John C, Ohagwu KA, Imoh ME, et al. (2013) Prevalence of overweight and obesity in adult Nigerians - a systematic review. Diabetes Metab Syndr Obes 6: 43-47.

21. Azoh AJC, Azoh AJC, Lokrou A (2009) P71 Influence de la parité sur le tour de taille chez la noire africaine en Côte-d'Ivoire. À propos de 181 cas colligés dans le service d'endocrinologie diabétologie du CHU de Yopougon Abidjan. Diabetes Metab 35: A45.

22. Boutayeb A, Boutayeb S (2005) The burden of non communicable diseases in developing countries. Int J Equity Health $4: 2$.

23. Adeboye B, Bermano G, Rolland C (2012) Obesity and its health impact in Africa: a systematic review. Cardiovasc J Afr 23: 512-521.

24. Zeba AN, Delisle HF, Renier G, Savadogo B, Baya B (2012) The double burden of malnutrition and cardiometabolic risk widens the gender and socio-economic health gap: a study among adults in Burkina Faso (West Africa). Public Health Nutr 15: 2210-2219.

25. Expert Panel on Detection, Evaluation, and Treatment of High Blood Cholesterol in Adults (2001) Executive Summary of the Third Report of 
Citation: Sagna Y, Yanogo DA, Tieno H, Guira O, Bagbila A et al. (2014) Obesity and Metabolic Syndrome in a Burkina Faso Urban Area: Prevalence, Associated Factors and Comorbidities. J Nutr Disorders Ther 4: 141. doi:10.4172/2161-0509-4.1000141

Page 6 of 6

the National Cholesterol Education Program (NCEP) Expert Panel on Detection, Evaluation, and Treatment of High Blood Cholesterol in Adults (Adult Treatment Panel III). JAMA J Am Med Assoc 285: 24862497.
26. Crowther NJ, Norris SA (2012) The current waist circumference cut point used for the diagnosis of metabolic syndrome in sub-Saharan African women is not appropriate. PLoS One 7: e48883. 